Biogeosciences Discuss., 5, 435-462, 2008

www.biogeosciences-discuss.net/5/435/2008/

(c) Author(s) 2008. This work is licensed

under a Creative Commons License.

Biogeosciences Discussions is the access reviewed discussion forum of Biogeosciences
Biogeosciences

Discussions
BGD

$5,435-462,2008$

Diel changes of BP and UV in the South

Pacific

F. Van Wambeke et al.

\section{Diel variability of heterotrophic bacterial production and UV doses in the South East Pacific}

F. Van Wambeke ${ }^{1}, M$. Tedetti $^{1}$, S. Duhamel ${ }^{1,2}$, and R. Sempéré ${ }^{1}$

${ }^{1}$ Laboratoire de Microbiologie, Géochimie et Ecologie Marines (LMGEM), CNRS UMR 6117, Université de la Méditerranée, Campus de Luminy - Case 901, 13288 Marseille cedex 9,

France

${ }^{2}$ Laboratoire d'Océanographie et de Biogéochimie (LOB), CNRS UMR 6535, Université de la Méditerranée, Campus de Luminy - Case 901, 13288 Marseille cedex 9, France

Received: 28 November 2007 - Accepted: 14 December 2007 - Published: 31 January 2008

Correspondence to: F. Van Wambeke (france.van-wambeke@univmed.fr)
Title Page

Abstract

Introduction

Conclusions

References

Tables

Figures

14

I

4

Back

Close

Full Screen / Esc

Printer-friendly Version

Interactive Discussion 


\section{Abstract}

Diel variability of heterotrophic bacterial production (BP) was investigated in the South East Pacific from October to December 2004 during the BIOSOPE cruise. Three sites differing by their trophic status were studied: Marquesas Islands (MAR; $08^{\circ} \mathrm{S}, 141^{\circ} \mathrm{W}$ ), 5 the centre of the South Pacific Gyre (SPG) (GYR; $26^{\circ} \mathrm{S}, 114^{\circ} \mathrm{W}$ ) and the eastern part of the SPG (EGY; $\left.32^{\circ} \mathrm{S}, 91^{\circ} \mathrm{W}\right)$. At the three sites, diel variability of BP ranged from 17 to $40 \%$ and from 13 to $22 \%$ for volumetric surface $(5 \mathrm{~m})$ and integrated (to $Z_{e}$ and $Z_{m}$ ) data, respectively. The main feature we observed was at $5 \mathrm{~m}$, an abrupt increase $(\times 2$ to $\times 4)$ in leucine activity during the afternoon-sunset period (12:00-18:00 at the site MAR and 15:00-21:00 at the site GYR) and lowest activities recorded between 10:00 and 14:00. To assess the potential influence of solar ultraviolet radiation (UVR: 280-400 nm) on this BP diel variability, we determined, from in situ optical measurements, the mean tri-hourly ultraviolet B (UVB, $305 \mathrm{~nm}$ ) and ultraviolet A (UVA, $380 \mathrm{~nm}$ ) doses (irradiances integrated over time) within the mixed layer $\left(H_{m}(\mathrm{UVB})\right.$ and $H_{m}(\mathrm{UVA})$, 15 respectively). The wavelengths $305 \mathrm{~nm}$ and $380 \mathrm{~nm}$ were used as biologically effective wavelengths for the induction of DNA damages (cyclobutane pyrimidine dimers: CPDs) and photoenzymatic repairs (PERs), respectively. In the SPG, daily $H_{m}$ (UVB) and $H_{m}(\mathrm{UVA})$ were 0.6 and $14 \mathrm{~kJ} \mathrm{~m}^{-2} \mathrm{~nm}^{-1}$, respectively. The latter were probably the highest daily doses ever measured in the marine environment. The $H_{m}(\mathrm{UVB}) / H_{m}(\mathrm{UVA})$ ratio $(Q)$ increased by 58,117 and $46 \%$ from 06:00-09:00 to 12:00-15:00, and decreased by 36,26 and $16 \%$ from 12:00-15:00 to 15:00-18:00 at the sites MAR, GYR and EGY, respectively. The relationship between $Q$ and BP suggested a significant influence of UVR on the diel variability of BP (BP decreased when $Q$ increased) at the site GYR from the surface waters to $Z_{m}$, likely in relation with its hyper-oligotrophic status. Therefore, possible alternance of CPD and PER periods attributed to $Q$ ratio, as well as a strong lags between process of autotrophic production with their associated dissolved organic carbon (DOC) release and heterotrophic utilization of organic matter could explain such diel variations.
BGD

5, 435-462, 2008

Diel changes of BP and UV in the South Pacific

F. Van Wambeke et al.

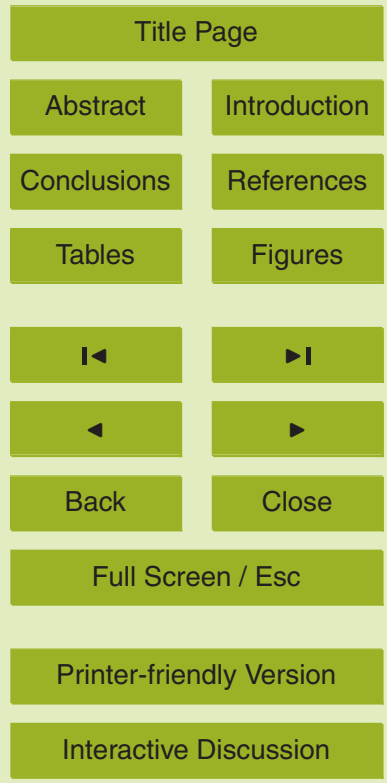

EGU 


\section{Introduction}

Abundance and growth of heterotrophic bacteria are under the influence of many parameters which vary at different time scales. In open oceans, since the main source of dissolved organic matter (DOM) is primary production (PP), interactions between phy5 toplankton and heterotrophic bacteria are likely stronger than in coastal areas. Hence, short term/diel variations of heterotrophic bacterial production (BP) could occur more intensively in oligotrophic environments (Gasol et al., 1998; Shiah, 1999). However, in addition to substrate supply: DOM and inorganic nutrients (bottom-up control; Kuipers et al., 2000), other factors may also affect BP at diel scale in open oceans: bacterivory and viral lysis (top-down control; Christaki et al., 2002; Winter et al., 2004), and solar radiation.

The context of climate change and stratospheric ozone depletion has stimulated interest in investigating the effects of solar radiation, and more specifically ultraviolet radiation (UVR: $280-400 \mathrm{~nm}$ ), on BP (Häder et al., 2003). In the surface waters, UVR can significantly affect heterotrophic bacteria that are too small to efficiently use UVR-absorbing pigments as sunscreens (Garcia-Pichel, 1994). Ultraviolet B (UVB: $280-315 \mathrm{~nm}$ ) is strongly absorbed by cellular DNA, altering thus its structure and producing damages such as cyclobutane pyrimidine dimers (CPDs) (Buma et al., 2003; Häder and Sinha, 2005). Many studies have reported the inhibition of BP after the UVB exposure of natural microbial assemblages and the subsequent production of CPDs (Aas et al., 1996; Jeffrey et al., 1996). On the other hand, DNA damages can be repaired through two pathways: (i) photoenzymatic repairs (PERs) via the action of photolyase, induced by both ultraviolet A (UVA: $315-400 \mathrm{~nm}$ ) and photosynthetically available radiation (PAR: $400-700 \mathrm{~nm}$ ) and (ii) excision repairs that occur in the dark 25 (Buma et al., 2003; Häder and Sinha, 2005). PERs have been observed in natural assemblages and bacterial cultures exposed to artificial UVB after secondary irradiation with UVA and PAR (Kaiser and Herndl, 1997; Joux et al., 1999). It appeared that UVA was always more efficient than PAR in inducing photoreactivation (Kaiser and Herndl,
BGD

$5,435-462,2008$

Diel changes of BP and UV in the South Pacific

F. Van Wambeke et al.

Title Page

Abstract Introduction

Conclusions

Tables

References

Figures

14

I

4

Back

Close

\section{Full Screen / Esc}

Printer-friendly Version

Interactive Discussion 
1997; Joux et al., 1999). Therefore, the rates of CPDs and PERs in marine microbial assemblages may be related to the UVB and UVA doses (irradiances integrated over time) received by cells (Boelen et al., 2001). In the surface ocean, the intensity of UVB and UVA doses for a given time period depends on several parameters: (i) the level of 5 surface UVB and UVA irradiances, (ii) the attenuation of these surface irradiances in the water column, which is mainly controlled by chromophoric DOM (CDOM) (Diaz et al., 2000) and (iii) the depth of the mixed layer $\left(Z_{m}\right)$, i.e. the depth at which cells can be transported within the upper water column (Boelen et al., 2001). When studying the impact of UVR on heterotrophic bacteria in the surface waters, as cells are subjected to 10 vertical mixing, it seems more appropriate to consider the mean UVB and UVA doses received within the mixed layer than those received beneath the sea surface or at other fixed depths.

The Blogeochemistry and Optics SOuth Pacific Experiment (BIOSOPE) French project was dedicated to a pluridisciplinary exploration of the South East Pacific in15 cluding the hyper-oligotrophic South Pacific Gyre (SPG) as well as its western (Marquesas Islands) and eastern (Chilean upwelling) borders in late 2004 (Claustre et al., 2008). As in other subtropical regions, the South East Pacific is subjected to high surface UVB and UVA irradiances due to the small solar zenith angle (SZA) and the relatively low ozone amounts (200-300 Dobson Units) (TOMS satellite data; http://toms.gsfc.nasa.gov/ozone/ozone_v8.html). Moreover, the very low content in chlorophyll a (Chla) and CDOM in the highly stratified surface waters of the SPG allows for a very deep penetration of UVR (Morel et al., 2007; Tedetti et al., 2007). In the surface layers of this oceanic area, nitrogen has been shown to be a common factor limiting both phytoplankton and heterotrophic bacteria (Bonnet et al., 2007; Van Wambeke et al., 2007a). Consequently, in the SPG, the diel variability of BP could be particularly intense, influenced by the UVB and UVA doses received within the mixed layer (i.e. alternance of CPDs and PERs), but also the trophic dependence of heterotrophic bacteria on phytoplankton exudates and/or regeneration processes.

The main goals of the present study are (i) to determine the diel variability of BP in the

\section{BGD}

$5,435-462,2008$

Diel changes of BP and UV in the South Pacific

F. Van Wambeke et al.

Title Page

Abstract

Introduction

Conclusions

Tables

References

Figures

14

$\rightarrow$

4

Back

Close

Full Screen / Esc

Printer-friendly Version

Interactive Discussion 
South East Pacific at three selected sites differing by their trophic status: Marquesas Islands, the centre and the eastern border of the SPG and (ii) to assess the potential influence of UVR on this diel variability by calculating the mean tri-hourly UVB and UVA doses received by heterotrophic bacteria within the mixed layer.

BGD

$5,435-462,2008$

Diel changes of BP and UV in the South Pacific

\subsection{Strategy of sampling}

The BIOSOPE cruise was conducted from 24 October to 11 December 2004 aboard R/V Atalante in the South East Pacific. The cruise consisted of "short" stations and "long" sites, where the possibility was offered to sample every $3 \mathrm{~h}$ during successive 10 days. Diel variability of BP was estimated at three of these long sites, which were abbreviated according to their location: MAR (in the vicinity of Marquesas Islands), GYR (centre of the SPG) and EGY (eastern part of the SPG) (Fig. 1). These sites differed in terms of physical and biological characteristics (Claustre et al., 2008; Table 1). All the samples were collected from a CTD rosette fitted with 20 12-I Niskin bottles equipped with Teflon rings. After water collection, samples were processed within $0.5 \mathrm{~h}$ of collection.

\subsection{Heterotrophic bacterial production}

BP was determined by $\left[{ }^{3} \mathrm{H}\right]$ leucine incorporation applying the centrifugation method (Smith and Azam, 1992). The detailed protocol is available in Van Wambeke et al. (2007b). Briefly, incubation periods were about $2 \mathrm{~h}$ in the dark at the respective in situ temperatures, and the conversion factor employed was $1.5 \mathrm{~kg} \mathrm{C}$ per mole leucine incorporated. Error associated to the variability between replicate measurements (half the difference between the two replicates) averaged 13 and $6 \%$ for BP values less and more than $10 \mathrm{ng} \mathrm{Cl}^{-1} \mathrm{~h}^{-1}$, respectively. Note that because Archaea are not absent from

\section{F. Van Wambeke et al.}

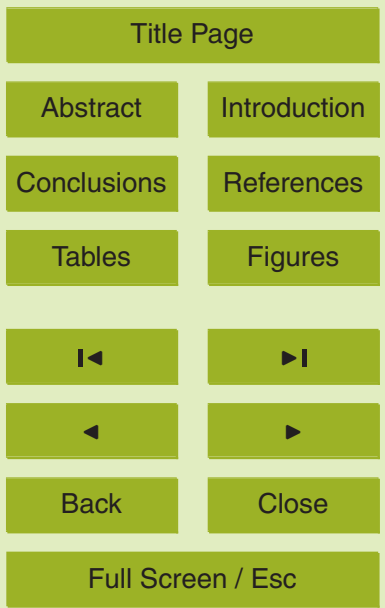

Printer-friendly Version

Interactive Discussion 
surface waters, and because it has been shown that they can assimilate leucine, BP corresponds sensus stricto to heterotrophic prokaryotic production, not to heterotrophic bacterial production.

BGD

$5,435-462,2008$

\subsection{UVR measurements and determination of mean tri-hourly UVB and UVA doses}

5 Two profiles of downward irradiance $\left(E_{d}(Z, \lambda)\right.$ in $\left.\mu \mathrm{W} \mathrm{cm}^{-2} \mathrm{~nm}^{-1}\right)$ were made at each site close to solar noon using a Satlantic MicroPro free-fall profiler equipped with OCR504 downward irradiance sensors in the UVB $(305 \mathrm{~nm})$ and UVA $(325,340$ and $380 \mathrm{~nm})$ spectral domains. Surface irradiance $\left(E_{d}\left(0^{+}, \lambda\right)\right.$ in $\left.\mu \mathrm{W} \mathrm{cm}^{-2} \mathrm{~nm}^{-1}\right)$ was simultaneously measured at the same channels on the ship deck using other OCR-504 sensors to account for the variations of cloud conditions during the cast as well as to monitor UVB and UVA irradiances during the day time. For in-water and in-air sensors, the FullWidth Half-Maximum (FWHM) of the channels was $2 \mathrm{~nm}$ for 305,325 and $340 \mathrm{~nm}$, and $10 \mathrm{~nm}$ for $380 \mathrm{~nm}$. A detailed description of UVR measurements is given elsewhere (Tedetti et al., 2007).

To evaluate the potential influence of UVR on BP, the mean tri-hourly UVB and UVA doses within the mixed layer $\left(H_{m}(\mathrm{UVB})\right.$ and $H_{m}(\mathrm{UVA})$, respectively) were determined at the sites MAR (28 October), GYR (13 November) and EGY (26 November). The wavelengths $305 \mathrm{~nm}$ (UVB) and $380 \mathrm{~nm}$ (UVA) were used as biologically effective wavelengths for the induction of CPDs and PERs, respectively (Häder and Sinha, 2005). $H_{m}(\mathrm{UVB})$ and $H_{m}(\mathrm{UVA})$ were calculated using the following formula (Helbling et al., 1994; Boelen et al., 2000):

$H_{m}(\lambda)=\left(H\left(0^{-}, \lambda\right) \times\left(1-\exp \left(-K_{d}(\lambda) \times Z_{m}\right)\right)\right) /\left(K_{d}(\lambda) \times Z_{m}\right)$

where $H_{m}(\lambda)$ is mean tri-hourly dose within the mixed layer $\left(\mathrm{kJ} \mathrm{m}^{-2} \mathrm{~nm}^{-1}\right), H\left(0^{-}, \lambda\right)$ is tri-hourly dose beneath the sea surface $\left(\mathrm{kJ} \mathrm{m}^{-2} \mathrm{~nm}^{-1}\right), K_{d}(\lambda)$ is diffuse attenuation 25 coefficient for downward irradiance $\left(\mathrm{m}^{-1}\right)$ and $Z_{m}$ is mixed layer depth $(\mathrm{m})$, evaluated from CTD profiles (Table 1). Wavelength $\lambda$ is 305 or $380 \mathrm{~nm}$.
Diel changes of BP and UV in the South Pacific

F. Van Wambeke et al.

Title Page

Abstract Introduction

Conclusions

Tables References

Figures

14

Back

Close
Printer-friendly Version

Interactive Discussion 
$H\left(0^{-}, \lambda\right)$ was obtained by integrating downward irradiance beneath the sea surface $\left(E_{d}\left(0^{-}, \lambda\right)\right.$ in $\left.\mu \mathrm{W} \mathrm{cm}^{-2} \mathrm{~nm}^{-1}\right)$ over the exposure period:

$H\left(0^{-}, \lambda\right)=\Sigma E_{d}\left(0^{-}, \lambda, t\right) \Delta t$

The tri-hourly exposure periods used here were: 06:00-09:00, 09:00-12:00, 12:005 15:00 and 15:00-18:00) (local time). $E_{d}\left(0^{-}, \lambda\right)$ was theoretically computed from $E_{d}\left(0^{+}, \lambda\right)$ using the formula:

$E_{d}\left(0^{-}, \lambda\right)=E_{d}\left(0^{+}, \lambda\right) /(1+\alpha)$

where $\alpha$ is ocean surface albedo determined by using a look up table available online at http://www-cave.larc.nasa.gov/cave/ (Jin et al., 2004). This look up table, which 10 is based on the validated Coupled Ocean-Atmosphere Radiative Transfer (COART) model, requires four input parameters to retrieve $\alpha$ at any spectral band of the solar spectrum: SZA, wind speed, aerosol/cloud optical depth and Chla concentration (Jin et al., 2004). SZA $\left({ }^{\circ}\right)$ was obtained every hour from the T. Dibble's SZA calculator (http://www.esf.edu/chemistry/dibble/atmoschemcalc.htm) that uses location (latitude, longitude), date (day, month) and universal time (UT) of measurements. Wind speed (knots converted into $\mathrm{m} \mathrm{s}^{-1}$ ) was measured continuously on board. At the sites MAR and GYR (cloudless days), aerosol optical depth at $550 \mathrm{~nm}$ was estimated at 0.15 and 0.05 , respectively (Myhre et al., 2005). At the site EGY (cloudy day), cloud optical depth at $500 \mathrm{~nm}$ was assessed at 15 (second highest value used in the look up table). Chla 20 concentrations $\left(\mathrm{mg} \mathrm{m}^{-3}\right.$ ) were used from Tedetti et al. (2007). Therefore, $\alpha$, computed every hour at 305 and $380 \mathrm{~nm}$, was highly variable at the sites MAR (ranging from 0.050 at $12: 00$ to 0.097 at 17:00) and GYR (ranging from 0.057 at 12:00 to 0.108 at 07:00), and very stable at the site EGY ( 0.068 from 06:00 to 18:00).

$K_{d}(\lambda)$ was determined at each station close to solar noon from the slope of the linear 25
BGD

$5,435-462,2008$

Diel changes of BP and UV in the South Pacific

F. Van Wambeke et al.

Title Page

Abstract

Introduction

Conclusions

Tables

References

Figures

14

-1

4

Back

Close

Full Screen / Esc

Printer-friendly Version

Interactive Discussion

$K_{d}(\lambda)=\ln \left(E_{d}\left(0^{-}, \lambda\right) / E_{d}(Z, \lambda)\right) / Z$ 
where $E_{d}\left(0^{-}, \lambda\right)$ and $E_{d}(Z, \lambda)$ are downward irradiance beneath the sea surface (derived from Eq. 3) and downward irradiance at depth $Z$, respectively. $Z$ was $15 \mathrm{~m}$ (MAR) or $30 \mathrm{~m}$ (GYR and EGY). Determination coefficients $\left(r^{2}\right)$ of $K_{d}(\lambda)$ calculation were $>0.97$ for the three sites. Since $K_{d}(\lambda)$ was measured only close to solar noon, we assumed 5 here a constant $K_{d}(\lambda)$ value for the four tri-hourly periods. Because of the SZA increasing during the day time, $K_{d}(\lambda)$ was corrected for the geometric condition of the light field by dividing by Gordon's (1989) correction factor $\left(D_{o}(\lambda)\right)$ :

$D_{o}(\lambda)=\left(f(\lambda) / \cos \left(\operatorname{SZA}\left(0^{-}\right)\right)\right)+1.197 \times(1-f(\lambda))$

where $f(\lambda)$ is the direct fraction of global irradiance and SZA $\left(0^{-}\right)$is the SZA beneath 10 th available in the literature for the UV spectral domain (Kuhn et al 1999): 0.36 and 0.57 at 305 and $380 \mathrm{~nm}$, respectively for cloudless days (MAR and GYR). To facilitate the calculation, the site EGY was considered with an overcast sky, i.e. with no direct radiation $(f(\lambda)=0.00)$. SZA $\left(0^{-}\right)$was obtained by applying Snell's law to SZA above 15 water:

$\operatorname{SZA}\left(0^{-}\right)=\sin ^{-1}(\sin (\mathrm{SZA}) / n)$

where $n(\sim 1.34)$ is the refraction index of water. $D_{o}(\lambda)$, which is wavelength dependent, was computed every hour at 305 and $380 \mathrm{~nm}$ and then averaged over the tri-hourly periods. $D_{o}(\lambda)$ ranged from 1.11 (12:00-15:00) to 1.30 (06:00-09:00 and 15:00-18:00) at the sites MAR and GYR, whereas it was constant (1.197) at the site EGY. Assuming a vertical homogeneity of the distribution of attenuating substances and organisms over the depth interval $0^{-} \mathrm{m}$ to TChla maximum (Table 1$)$, the $10 \%$ irradiance depth $\left(Z_{10 \%}(\lambda)\right.$ in $\mathrm{m}$ ), which is the depth where the downward irradiance is $10 \%$ of its surface value, was extrapolated from $K_{d}(\lambda)$ :

${ }_{25} \quad Z_{10 \%}(\lambda)=\ln (10) / K_{d}(\lambda)=2.30 / K_{d}(\lambda)$

\section{BGD}

$5,435-462,2008$

Diel changes of BP and UV in the South Pacific

F. Van Wambeke et al.

Title Page

Abstract

Introduction

Conclusions

Tables

References

Figures

14

-1

4

Back

Close

Full Screen / Esc

Printer-friendly Version

Interactive Discussion 


\section{Results}

\subsection{Physical, biological and optical characteristics}

The main physical and biological characteristics of the three sites studied for diel variability of BP are presented Table 1 . Mean surface temperature $(5 \mathrm{~m})$ was slightly higher 5 at the site MAR $\left(27.8^{\circ} \mathrm{C}\right)$ compared to the sites GYR and EGY $\left(22.3\right.$ and $18.1^{\circ} \mathrm{C}$, respectively). The variations of temperature during the diel cycles were very low, as seen by standard errors $\left(<0.14^{\circ} \mathrm{C}\right.$, Table 1$)$. In terms of depth of TChla maximum $(176 \mathrm{~m})$, depth of the euphotic zone $\left(Z_{e}: 1 \%\right.$ PAR, $\left.155 \mathrm{~m}\right), Z_{10 \%}$ (UVA) $(110 \mathrm{~m})$ and $Z_{10 \%}$ (UVB) $(23 \mathrm{~m})$, the site GYR confirmed its hyper-oligotrophic status, whereas the sites EGY and MAR were more classically oligotrophic (Table 1). From data acquired during the diel cycles, BP values at $5 \mathrm{~m}$ depth were on average 63,17 and $29 \mathrm{ng} \mathrm{Cl}^{-1} \mathrm{~h}^{-1}$ at the sites MAR, GYR and EGY, respectively. Corresponding integrated BP down to $Z_{e}$ and down to $Z_{m}$ were 168, 65 and $59 \mathrm{mg} \mathrm{C} \mathrm{m}^{-2} \mathrm{~d}^{-1}$, and 197,19 and $21 \mathrm{mg} \mathrm{C} \mathrm{m}^{-2} \mathrm{~d}^{-1}$, respectively (Table 1). Note that at the site MAR, $Z_{m}$ was on average deeper than $Z_{e}$ 15 leading to a higher value of integrated BP. From these results, it appears that the microbial populations at the site MAR were slightly more active than at the site EGY, in accordance with the ranges of PP rates obtained: 457-1146, 159-203 and $196 \mathrm{mg} \mathrm{C} \mathrm{m}^{-2} \mathrm{~d}^{-1}$ at the sites MAR, EGY and GYR, respectively (Van Wambeke et al., 2007b).

If we make the assumption that below $Z_{10 \%}$ (UVB) and below $Z_{10 \%}$ (UVA), irradiances received by cells become too low to induce substantial CPDs and PERs, at the site MAR, heterotrophic bacteria were probably not affected by UVB and UVA below $Z_{m}$ (even though UVB and UVA were effective within $Z_{m}$ because of the vertical mixing that transports cells to the surface) (Table 1). In the same way, at the sites GYR and EGY, heterotrophic bacteria were not affected by UVB below $Z_{m}$ and not affected by

UVA below $Z_{e}$ (Table 1). Consequently, the significant influence of both UVB and UVA on heterotrophic bacteria (alternance of CPDs and PERs) could not occur deeper than $Z_{m}$ at the site MAR and deeper than $Z_{m}$ or $Z_{e}$ at the sites GYR and EGY.
BGD

$5,435-462,2008$

Diel changes of BP and UV in the South Pacific

F. Van Wambeke et al.

Title Page

Abstract

Introduction

Conclusions

Tables

References

Figures

14

$\rightarrow$

4

Back

Close

Full Screen / Esc

Printer-friendly Version

Interactive Discussion 


\section{BGD}

For the three sites investigated, diel variations of BP were of great magnitude, considering both the subsurface layers (volumetric rates at $5 \mathrm{~m}$ depth) and integrated BP down to $Z_{e}$ or $Z_{m}$ (Fig. 2). Diel variability (standard deviation to mean ratio) for vol5 umetric data at $5 \mathrm{~m}$ depth ranged 24,40 and $17 \%$ at the sites MAR, GYR and EGY, respectively. At the site MAR, BP at $5 \mathrm{~m}$ depth increased up to 2.1 times between $12: 00$ and 18:00, and decreased from 18:00 to 12:00 more progressively. At the site GYR, a higher increase $(\times 4.7)$ in activity was recorded later, between 15:00 and 21:00 (Fig. 2). Again, the decrease was more progressive. Trend at the site EGY is more difficult to describe because of the longer interval between CTD casts (6h). However, higher BP values were associated to end afternoon-mid night period, with up to 1.5 times variations in $6 \mathrm{~h}$. Considering integrated data, diel variability of BP integrated to $Z_{e}$ ranged 13,16 and $19 \%$ at the sites MAR, GYR and EGY, respectively, while that of BP integrated to $Z_{m}$ were slightly higher at the site GYR only (22\%). At the site MAR, 5 the correlation between BP at $5 \mathrm{~m}$ and integrated data were low $(r=0.57$ for integration to $Z_{m}$ and $r=0.61$ for integration to $Z_{e}$; Table 2). On the contrary, there was a better correlation between BP at $5 \mathrm{~m}$ and BP integrated to $Z_{m}$ at the sites GYR and EGY ( $r=0.88$ and $r=0.90$, respectively; Table 2). However, the correlations were lower and insignificant when relating BP at $5 \mathrm{~m}$ with BP integrated to $Z_{e}$ at these sites $(r=0.55$ at the site GYR and relation insignificant at the site EGY; Table 2).

At the site MAR, the diel variability of volumetric rates at individual depths was not only visible at $5 \mathrm{~m}$ depth, but also down to $\sim 50 \mathrm{~m}$ depth (Fig. 3), with lower values during morning/noon and decreasing values during afternoon/night. At the opposite, the diel variability along other depths than surface was less visible at the site GYR. within $5 \mathrm{~m}$ depth and they occurred much deeper than at the site MAR (Fig. 3). On daily-averaged profiles of BP, subsurface peaks were still visible (Fig. 4).

5, 435-462, 2008

Diel changes of BP and UV in the South Pacific

F. Van Wambeke et al.

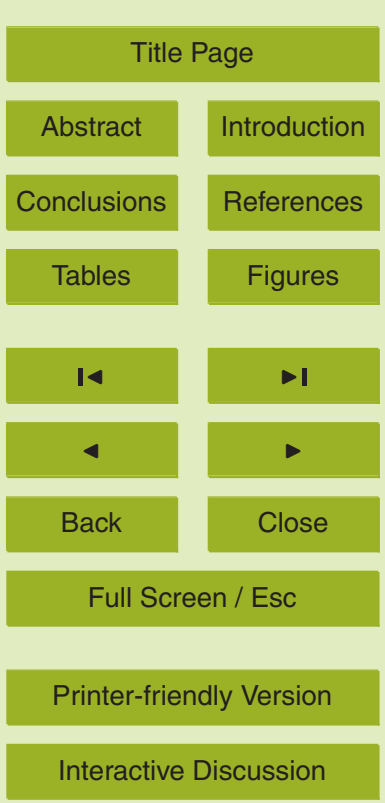

EGU 
$H_{m}(\mathrm{UVB})$ and $H_{m}$ (UVA), determined at the sites MAR (28 October), GYR (13 November) and EGY (26 November), are presented Table 3. Although 28 October and 13 November were cloudless days, 26 November was a cloudy day, as shown by the sur5 face PAR irradiance reported Fig. 2. At the site MAR, $H_{m}(\mathrm{UVB})$ and $H_{m}(\mathrm{UVA})$ ranged from 0.01 to $0.05 \mathrm{~kJ} \mathrm{~m}^{-2} \mathrm{~nm}^{-1}$ and from 0.42 to $1.71 \mathrm{~kJ} \mathrm{~m}^{-2} \mathrm{~nm}^{-1}$, respectively. The latter were much lower than the corresponding $H\left(0^{-}, \mathrm{UVB}\right)$ and $H\left(0^{-}, \mathrm{UVA}\right)(0.15-0.88$ and $\left.2.06-8.34 \mathrm{~kJ} \mathrm{~m}^{-2} \mathrm{~nm}^{-1}\right)$ due to relatively high values of $K_{d}(\lambda)\left(\sim 0.20\right.$ and $\left.0.06 \mathrm{~m}^{-1}\right)$ and $Z_{m}(\sim 96 \mathrm{~m})$ (Table 3). Indeed, $K_{d}(\lambda)$ and $Z_{m}$ are the two factors involved in the 10 determination of $H_{m}(\lambda)$ from $H\left(0^{-}, \lambda\right)$ (see Eq. 1). For a given $H\left(0^{-}, \lambda\right)$, when $K_{d}(\lambda)$ increases (i.e. UVR more attenuated) and/or $Z_{m}$ increases (i.e. cells transported deeper), $H_{m}(\lambda)$ decreases. At the site GYR, $H_{m}(\mathrm{UVB})$ and $H_{m}(\mathrm{UVA})$ were much higher, ranging from 0.02 to $0.31 \mathrm{~kJ} \mathrm{~m}^{-2} \mathrm{~nm}^{-1}$ and from 0.79 to $7.08 \mathrm{~kJ} \mathrm{~m}^{-2} \mathrm{~nm}^{-1}$, respectively. Even though $H\left(0^{-}, \mathrm{UVB}\right)$ and $H\left(0^{-}, \mathrm{UVA}\right)$ at this site $\left(0.12-0.99\right.$ and $\left.1.58-9.54 \mathrm{~kJ} \mathrm{~m}^{-2} \mathrm{~nm}^{-1}\right)$ 15 were close to those measured at the site MAR, $K_{d}(\lambda)\left(\sim 0.10\right.$ and $\left.0.02 \mathrm{~m}^{-1}\right)$ and $Z_{m}$ ( $\sim 50 \mathrm{~m}$ ) were considerably lower (Table 3$)$. At the site EGY, $H_{m}(\mathrm{UVB})$ and $H_{m}(\mathrm{UVA})$ ranged from 0.02 to $0.11 \mathrm{~kJ} \mathrm{~m}^{-2} \mathrm{~nm}^{-1}$ and from 0.80 to $3.40 \mathrm{~kJ} \mathrm{~m}^{-2} \mathrm{~nm}^{-1}$, respectively, and thus were higher than those recorded at the site MAR. This is explained by lower values of $K_{d}(\lambda)\left(\sim 0.16\right.$ and $\left.0.04 \mathrm{~m}^{-1}\right)$ and $Z_{m}(\sim 30 \mathrm{~m})$ despite the fact that $H\left(0^{-}, \mathrm{UVB}\right)$ 20 and $H\left(0^{-}\right.$, UVA) $\left(0.09-0.59\right.$ and $\left.1.30-5.73 \mathrm{~kJ} \mathrm{~m}^{-2} \mathrm{~nm}^{-1}\right)$ were largely reduced because of the cloud cover (Table 3$). H_{m}(\mathrm{UVB})$ and $H_{m}(\mathrm{UVA})$ were lower than the corresponding $H\left(0^{-}\right.$, UVB) and $H\left(0^{-}\right.$, UVA) on average by a factor 20 and 5 (MAR), 3 and 1.4 (GYR), and 5 and 1.6 (EGY). A more important diminution was observed for UVB because of its higher values of $K_{d}(\lambda)$ (Table 3). For the three sites, the highest values of $H_{m}(\mathrm{UVB})$ 25 and $H_{m}$ (UVA) were observed during the period 12:00-15:00 (except at the site MAR for $H_{m}$ (UVA): 09:00-12:00). Theses values represented 45 and 34\% (MAR), 56 and 50\% (GYR), and 44 and $42 \%$ (EGY) of the daily dose received during the period 06:0018:00.

\section{BGD}

5, 435-462, 2008

Diel changes of BP and UV in the South Pacific

F. Van Wambeke et al.

Title Page

Abstract

Introduction

Conclusions

Tables

References

Figures

14

$\rightarrow$

4

Back

Close

Printer-friendly Version

Interactive Discussion 
The $H_{m}(\mathrm{UVB}) / H_{m}(\mathrm{UVA})$ ratio ( $Q$ in \%) showed significant variations during the day time, ranging from 2.08 to $3.29 \%$, from 2.03 to $4.41 \%$ and from 2.29 to $3.35 \%$ at the sites MAR, GYR and EGY, respectively (Table 3). These minimal and maximal values were always detected at the periods $06: 00-09: 00$ and 12:00-15:00, respectively. $Q$ 5 increased by 58, 117 and 46\% from 06:00-09:00 to 12:00-15:00, and decreased by 36,26 and $16 \%$ from 12:00-15:00 to 15:00-18:00 at the sites MAR, GYR and EGY, respectively. Hence, the diel variability of $Q$ was more evident at the sites MAR and GYR than at the site EGY (Table 3).

\section{Discussion}

10 At the three sites studied (MAR, GYR and EGY), diel variability of BP ranged from 17 to $40 \%$ and from 13 to $22 \%$ for volumetric surface $\left(5 \mathrm{~m}\right.$ ) and integrated (to $Z_{e}$ and $Z_{m}$ ) data, respectively. Thus, the diel variability of BP was more pronounced at $5 \mathrm{~m}$ and decreased with depth. BP at $5 \mathrm{~m}$ was better correlated with BP integrated to $Z_{m}$ than with BP integrated to $Z_{e}$ (Table 2). The main feature we observed was at $5 \mathrm{~m}$, an abrupt 15 increase $(\times 2$ to $\times 4)$ in leucine activity during the afternoon-sunset period (12:00-18:00 at the site MAR and 15:00-21:00 at the site GYR) and lowest activities recorded between 10:00 and 14:00. Diel variability of BP has been reported for various marine environments. For instance, Torréton and Dufour (1996) found $10-14 \%$ of variability in a Tuamotu atoll lagoon (surface layer), and Gasol et al. (1998) 16-32\% in western 20 Mediterranean coastal waters (surface layer to TChla maximum depth), both the estimates based on thymidine technique. These latter authors also measured leucine incorporation, which provided a higher variability (10-70\%) than that obtained using thymidine. However, when studying the diel variability of BP, no consensus emerges about the period where activities reach maximal values: at night (Zohary and Robarts, 1992) at noon (Gasol et al., 1998) or no significant trend (Torréton and Dufour, 1996), with regard to the biogeochemical characteristics of the studied site and the depth considered. Consequently, the marked diel pattern in BP determined from high-

\section{BGD}

$5,435-462,2008$

Diel changes of BP and UV in the South Pacific

F. Van Wambeke et al.

Title Page

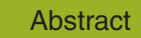

Introduction

Conclusions

Tables

References

Figures

14

$\rightarrow 1$

4

Back

Close

Full Screen / Esc

Printer-friendly Version

Interactive Discussion 
frequency sampling at the sites MAR, GYR and EGY support the hypothesis that daily variations of factors controlling BP, either physical (solar UVR) or biological (bottom-up control/top-down control) might be particularly pronounced in the South East Pacific (Figs. 2 and 3 ).

5 In order to assess the potential influence of solar UVR on this BP diel variability, we evaluated at the sites MAR, GYR and EGY the mean tri-hourly doses within the mixed layer $\left(H_{m}(\lambda)\right)$. Indeed, $H_{m}(\mathrm{UVB})$ at $305 \mathrm{~nm}$ and $H_{m}(\mathrm{UVA})$ at $380 \mathrm{~nm}$ can be used as estimates of the DNA damage (CPDs) and photoenzymatic repair (PERs) rates in bacterioplankton (Häder and Sinha, 2005). The differences observed at the three sites 10 between the tri-hourly doses received beneath the sea surface $\left(H\left(0^{-}, \lambda\right)\right)$ and $H_{m}(\lambda)$ $\left(\left(H_{m}(\lambda)\right.\right.$ lower than $H\left(0^{-}, \lambda\right)$ by a factor $1.4-20$; Table 3$)$ emphasize the importance of taking into account the vertical mixing as well as the UVR attenuation to determine the actual doses received by organisms in the surface waters. Boelen et al. (2000) reported similar differences with mean biologically effective doses in the mixed layer $15\left(\mathrm{BED}_{m}\right)$ lower than biologically effective doses beneath the sea surface $\left(\operatorname{BED}\left(0^{-}\right)\right)$by a factor 3-16. In the same way, Jeffrey et al. (1996) observed from depth profiles of DNA damages that wind-driven surface mixing had a significant impact on the distribution of CPDs in the water column. Daily $H_{m}$ (UVB) and $H_{m}$ (UVA) (from 06:00 to 18:00) were 0.11 and $4.15 \mathrm{~kJ} \mathrm{~m}^{-2} \mathrm{~nm}^{-1}$ (MAR), 0.55 and $14.09 \mathrm{~kJ} \mathrm{~m}^{-2} \mathrm{~nm}^{-1}$ (GYR) and 0.25 and $20 \quad 8.05 \mathrm{~kJ} \mathrm{~m}^{-2} \mathrm{~nm}^{-1}$ (EGY) (Table 3). Since at the site GYR $H\left(0^{-}, \lambda\right)$ values were close to those at the site MAR and $Z_{m}$ was deeper than at the site EGY, the higher $H_{m}(\lambda)$ encountered in this area were explained by the very low attenuation of UVR in the water column $\left(K_{d}(\lambda): 0.09\right.$ and $\left.0.02 \mathrm{~m}^{-1}\right)$. Indeed, it has been shown that the SPG was likely the most oligotrophic oceanic regime (Claustre and Maritorena, 2003) con25 taining the clearest natural waters (Morel et al., 2007). Although $H_{m}(\lambda)$ seems more appropriate than $H\left(0^{-}, \lambda\right)$ to describe the potential effect of UVR on heterotrophic bacteria in the surface ocean, little is reported about $H_{m}(\lambda)$ data. In the tropical Atlantic Ocean, Boelen et al. (2000) found daily $\mathrm{BED}_{m}$ ranging between 0.11 and $0.56 \mathrm{~kJ} \mathrm{~m}^{-2}$. These BEDs were determined from the DNA action spectrum of Setlow (1974) normal-

\section{BGD}

$5,435-462,2008$

Diel changes of BP and UV in the South Pacific

F. Van Wambeke et al.

Title Page

Abstract

Introduction

Conclusions

Tables

References

Figures

14

$\rightarrow$

4

Back

Close

Full Screen / Esc

Printer-friendly Version

Interactive Discussion 
ized at $300 \mathrm{~nm}$. Thus, they may be comparable to our daily $H_{m}(\mathrm{UVB})$, which ranged $0.11-0.55 \mathrm{~kJ} \mathrm{~m}^{-2} \mathrm{~nm}^{-1}$. At the site GYR, daily $H\left(0^{-}, \mathrm{UVB}\right)$ and $H\left(0^{-}, \mathrm{UVA}\right)$ were 2.00 and $20.47 \mathrm{~kJ} \mathrm{~m}^{-2} \mathrm{~nm}^{-1}$, respectively (Table 3 ). These values are in the same range than daily doses above the sea surface measured at 305 and $380 \mathrm{~nm}\left(H\left(0^{+}, \mathrm{UVB}\right)\right.$ and $5 H\left(0^{+}\right.$, UVA $\left.)\right)$in the subtropical Atlantic Ocean $\left(1.7\right.$ and $19 \mathrm{~kJ} \mathrm{~m}^{-2} \mathrm{~nm}^{-1}$; Obernosterer et al., 2001), in Antarctic waters (1.6 and $25 \mathrm{~kJ} \mathrm{~m}^{-2} \mathrm{~nm}^{-1}$; Figueroa et al., 2002) and in the northwestern Mediterranean Sea $\left(1.5\right.$ and $21 \mathrm{~kJ} \mathrm{~m}^{-2} \mathrm{~nm}^{-1}$; Tedetti and Sempéré, unpublished data). Nevertheless, if the whole UVB (integration over $280-315 \mathrm{~nm}$ ) and UVA (integration over $315-400 \mathrm{~nm}$ ) spectra are considered, $\mathrm{H}\left(\mathrm{O}^{+}, \mathrm{UVB}\right)$ and $\mathrm{H}\left(\mathrm{O}^{+}, \mathrm{UVA}\right)$ 10 become much higher. For example, in the South Atlantic Ocean, Buma et al. (2001) measured with the broad band ELDONET radiometer $H\left(0^{+}, \mathrm{UVB}\right)$ and $H\left(0^{+}, \mathrm{UVA}\right)$ of 40 and $1800 \mathrm{~kJ} \mathrm{~m}^{-2}$, respectively. Consequently, the UVB (at $305 \mathrm{~nm}$ ) and UVA (at $380 \mathrm{~nm}$ ) doses received by heterotrophic bacteria beneath the sea surface and within the mixed layer that we report here for the South East Pacific, and more particularly for 15 the SPG, are among the highest doses ever recorded for the marine environment.

The $H_{m}(\mathrm{UVB}) / H_{m}(\mathrm{UVA})$ ratio $(Q$ in \%) presented significant variations during the day time, with highest values reached around solar noon (09:00-12:00 and 12:00-15:00) and lower values at the end and beginning of the day (06:00-09:00 and 15:00-18:00) (Table 3). The higher relative contribution of UVB-induced DNA damages (such as CPDs) around solar noon could be related to the low values of BP at $5 \mathrm{~m}$ and BP integrated to $Z_{m}$ between 10:00 and 14:00 (Fig. 2). Jeffrey et al. (1996) demonstrated that UVB was responsible for $85 \%$ of the total leucine inhibition (30\% relative to dark controls) when heterotrophic bacteria were exposed to full solar radiation in surface waters. From the linear relationship between CPD formation in naked calf-thymus DNA dosimeters and UVB irradiance at $305 \mathrm{~nm}$ (Wilhem et al., 2002), we calculated a theorical production of CPDs within the mixed layer (regardless of photorepair processes): 420, 1300 and 700 CPDs (Mb DNA) ${ }^{-1}$ at the sites MAR, GYR and EGY, respectively. The daily production calculated at the site GYR was higher than that measured in surface DNA dosimeters: 500 CPDs (Mb DNA) ${ }^{-1}$ in the Gulf of Mexico (Jeffrey et al.,

BGD

$5,435-462,2008$

Diel changes of BP and UV in the South Pacific

F. Van Wambeke et al.

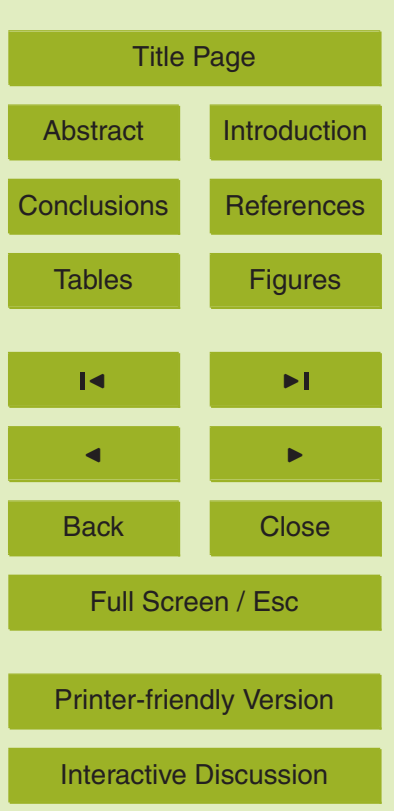

EGU 
1996) and 1000 CPDs (Mb DNA) ${ }^{-1}$ in the South coast of Curaçao (Boelen et al., 2001; Visser et al., 2002). The period 09:00-15:00 accounted for 67,80 and $69 \%$ of the daily production of CPDs at the sites MAR, GYR and EGY, respectively. Consequently, these high amounts of UVB-induced CPDs may lead to the inhibition of BP 5 around solar noon. On the other hand, the higher relative contribution of photorepairs (PERs) (i.e. lower $Q$ values) at the end of the afternoon (Table 3) may explain the abrupt increase or the less rapid decrease in BP at this period (Fig. 2). In tropical coastal waters, Visser et al. (2002) showed that the inhibition of leucine incorporation in bacterioplankton exposed to full solar radiation strongly increased from 10:00 to 12:30 or 15:00 (up to $80 \%$ of dark controls) and slightly increased or slightly decreased from 15:00 to 18:00. This less rapid inhibition of leucine incorporation in late afternoon was attributed to PERs. In order to better appreciate the potential impact of $Q$ (CPDs/PERs) to the diel variability of $\mathrm{BP}$, we examined the relationships between tri-hourly $Q$ (Table 3 ) and tri-hourly BP (BP integrated over three hours; data not shown) at the site MAR and GYR (EGY was excluded because of the lack of BP data). For the site MAR, there was no significant inverse linear relationship between $Q$ and $\mathrm{BP}(r=0.54, p>0.05)$. However, for the site GYR, we found a significant inverse linear relationship between $Q$ and BP at $5 \mathrm{~m}$ and between $Q$ and BP integrated to $Z_{m}(r=0.98$ and $0.97, p<0.05)$ but an insignificant relationship between $Q$ and BP integrated to $Z_{e}(r=0.76, p>0.05)$. These 20 results suggest that the influence of UVR on the diel variability of BP (BP decreases when $Q$ increases) is substantial at the site GYR from the surface waters to $Z_{m}$, likely in relation with its hyper-oligotrophic status, even though we did not conduct any irradiation experiment with heterotrophic bacteria exposed to solar radiation to confirm this findings.

25 In the surface oceanic layer, BP can be also affected indirectly by UVR through the photochemical transformation of DOM (Mopper and Kieber, 2002). Interestingly, DOM irradiation and biodegradation experiments, performed at the sites MAR, GYR and EGY, pointed out contrasted effects of solar radiation on the DOM bioavailability (Sempéré et al., 2008). At the sites MAR and EGY, irradiation of surface DOM led to

\section{BGD}

5, 435-462, 2008

Diel changes of BP and UV in the South Pacific

F. Van Wambeke et al.

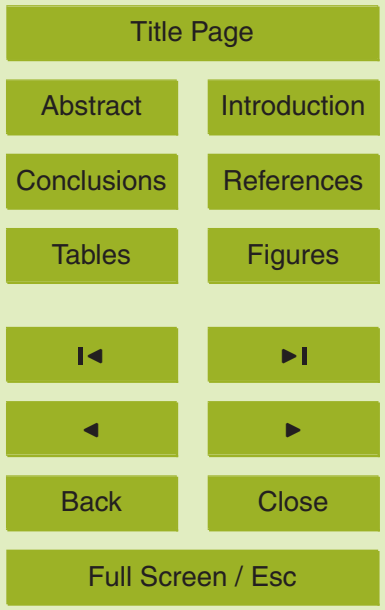

Printer-friendly Version

Interactive Discussion 
a stimulation of BP, whereas it had no significant effect at the site GYR (Sempéré et al., 2008). This implies for the sites MAR and EGY that some bioavailable compounds, photochemically produced from DOM during the day time, may be efficiently utilized by heterotrophic bacteria late in the afternoon when the UVB stress start decreasing 5 (i.e. when $Q$ start decreasing).

According to Maranon et al. (2005), dissolved organic carbon (DOC) produced by phytoplankton belongs to a pool of recently synthesized molecules with a high turnover rate and whose intracellular concentrations decreases quickly once photosynthesis stops. Therefore, phytoplankton extracellular release accumulation stops after the sun10 light period. If heterotrophic bacteria are closely related to this source of DOC to satisfy their needs for growth, they should be completely coupled to photosynthesis during the day time. Marked diel cycles in heterotrophic bacterial production are thus more expected in oligotrophic areas (Gasol et al., 1998; Church et al., 2004) due to the coupling with photosynthesis. However, because of the UVB-induced production of CPDs 15 around solar noon, there is a delay before BP increasing, which is detected when $Q$ start decreasing, i.e. after 15:00 (Table 3). Such succession could explain the apparent lag between process of photosynthesis, PP (as seen from beam attenuation coefficient used as a proxy of biomass changes; Claustre et al., 2007) and BP. Nevertheless, although the penetration of UVR was particularly important in the SPG (Table 1), it seems improbable, as discussed above, that the concomitant effect UVB/UVA would be the only parameter influencing integrated BP down to $Z_{e}$.

The pronounced diel pattern observed in the present study for heterotrophic bacterial production, delayed with that of primary production, suggests a dual control by phytoplankton as producers of labile organic matter at a daily scale in the South East 25 Pacific and by the quality and intensity of natural solar radiation (UVB, UVA and PAR) affecting also heterotrophic bacterial production.

Acknowledgements. The authors thank $\mathrm{H}$. Claustre for leadership of the BIOSOPE project, A. Sciandra for his leadership during the second leg, C. Bournot, D. Taillez and D. Merien for CTD operations and the crew of the R. V. Atalante for their help during the cruise, This research
BGD

$5,435-462,2008$

Diel changes of BP and UV in the South Pacific

F. Van Wambeke et al.

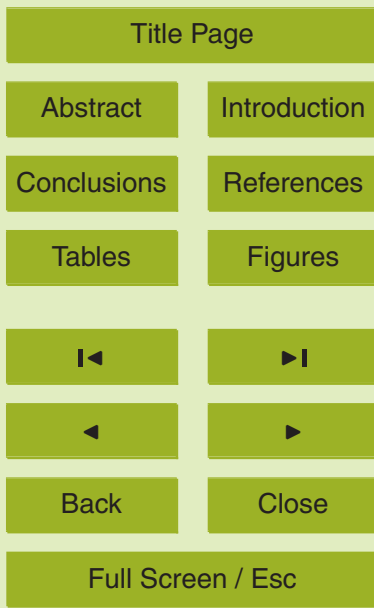

Printer-friendly Version

Interactive Discussion 


\section{References}

Aas, P., Lyons, M. M., Pledger, R., Mitchell, D. L., and Jeffrey, W. H.: Inhibition of bacterial activities by solar radiation in nearshore waters and the Gulf of Mexico, Aquat. Microb. Ecol., 11, 229-238, 1996.

Boelen, P., de Boer, M. K., Kraay, G. W., Veldhuis, M. J., and Buma, A. G.: UVBR-induced DNA damage in natural marine picoplankton assemblages in the tropical Atlantic Ocean, Mar. Ecol. Prog. Ser., 193, 1-9, 2000.

Boelen, P., Veldhuis, M. J., and Buma, A. G.: Accumulation and removal of UVBR-induced DNA damage in marine tropical plankton subjected to mixed and simulated non-mixed conditions, Aquat. Microb. Ecol., 24, 265-274, 2001.

Bonnet, S., Guieu, C., Bruyant, F., Prasil, O., Van Wambeke, F., Raimbault, P., Grob, C., Moutin, T., Gorbunov, M., Zehr, J. P., Masquelier, S., Garczareck, L., and Claustre, H.: Nutrients limitation of primary productivity in the Southeast Pacific (BIOSOPE cruise), Biogeosciences Discuss., 4, 2733-2759, 2007, http://www.biogeosciences-discuss.net/4/2733/2007/.

Buma, A. G., Helbling E. W., Boer, M. K., and Villafañe, V. E.: Patterns of DNA damage and photoinhibition in temperate South-Atlantic picophytoplankton exposed to solar ultraviolet radiation, J. Photochem. Photobiol. B: Biol., 62, 9-18, 2001.

Buma, A. G., Boelen, P., and Jeffrey, W. H.: UVR-induced DNA damage in aquatic organisms, in: UV effects in aquatic organisms and ecosystems, edited by: Helbling, E. W. and Zagarese, H. E., Cambridge, 291-327, 2003.

Christaki, U., Courties, C., Karayanni, H., Giannakourou, A., Maravelias, C., Kormas, K., and Lebaron, P.: Dynamic characteristics of Prochlorococcus and Synechococcus consumption 25 by bacterivorous nanoflagellates, Microb. Ecol., 43, 341-352, 2002.

Church, M. J., Ducklow, H. W., and Karl, D. A.: Light dependence of [H-3]leucine incorporation in the oligotrophic North Pacific ocean, Appl. Environ. Microbiol., 70, 4079-4087, 2004.

Claustre, H., Huot, Y., Obernosterer, I., Gentili, B., Tailliez, D., and Lewis, M.: Gross community production and metabolic balance in the South Pacific Gyre, using a non intrusive bio-optical

Diel changes of BP and UV in the South Pacific

F. Van Wambeke et al.

Title Page

Abstract

Introduction

Conclusions

Tables

References

Figures

14

$\triangleleft$

Back

Close

Full Screen / Esc

Printer-friendly Version

Interactive Discussion 
method, Biogeosciences Discuss., 4, 3089-3121, 2007,

http://www.biogeosciences-discuss.net/4/3089/2007/.

Claustre, H. and Maritonera, S.: The many shades of ocean blue, Science, 302, 1514-1515, 2003.

5 Claustre, H., Sciandra, A., and Vaulot, D.: Introduction to the special section Bio-optical and biogeochemical conditions in the South East Pacific in late 2004: the BIOSOPE program, Biogeosciences Discuss., in press, 2008.

Cole, J. J., Findlay, S., and Pace, M. L.: Bacterial production in fresh and saltwater ecosystems: a cross - system overview, Mar. Ecol. Prog. Ser., 43, 1-10, 1988.

10 Diaz, S. B., Morrow, J. H., and Booth, C. R.: UV physics and optics, in: The effects of UV radiation in the marine environment, edited by: de Mora, S., Demers, S., and Vernet, M., Cambridge University Press, Cambridge, 35-71, 2000.

Fernàndez, M., Bianchi, M., and Van Wambeke, F.: Bacterial biomass, heterotrophic production and utilization of dissolved organic matter photosynthetically produced in the Almeria-Oran

15 front, J. Mar. Syst., 5, 313-325, 1994.

Figueroa, F. L.: Bio-optical characteristics of Gerlache and Bransfield Strait waters during an Antarctic summer cruise, Deep-Sea Res. II., 49, 675-691, 2002.

Garcia-Pichel, F.: A model for internal self-shading in planktonic organisms and its implications for the usefulness of ultraviolet sunscreens, Limnol. Oceanogr., 39, 1704-1717, 1994.

Gasol, J. M., Doval, M. D., Pinhassi, J., Calderon-Paz, J. I., Guixa-Boixareu, N., Vaqué, D., and Pedros-Alio, C.: Diel variations in bacterial heterotrophic activity and growth in the northwestern Mediterranean Sea, Mar. Ecol. Prog. Ser., 164, 107-124, 1998.

Gordon, H.: Can the Lambert-Beer law be applied to the diffuse attenuation coefficient of ocean water?, Limnol. Oceanogr., 34, 1389-1409, 1989.

Häder, D. P. and Sinha, R. P.: Solar ultraviolet radiation-induced DNA damage in aquatic organisms: potential environmental impact, Mutation Res., 571, 221-223, 2005.

Häder, D. P., Kumar, H. D., and Smith, R. C.: Aquatic ecosystems: effects of solar ultraviolet radiation and interactions with other climatic change factors, Photochem. Photobiol. Sci., 2, 39-50, 2003.

30 Helbling, E. W., Villafane, V., and Holm-Hansen, O.: Effects of ultraviolet radiation on Antarctic marine photosynthesis with particular attention to the influence of mixing, in: Ultraviolet radiation in Antarctica: measurements and biological effects, edited by: Weiler, C. S. and Penhale, P. A., Antarctic Res. Ser. 62, American Geophysics Union, Washington D.C., 207-

Diel changes of BP and UV in the South Pacific

F. Van Wambeke et al.

Title Page

Abstract

Introduction

Conclusions

Tables

References

Figures

14

$\rightarrow$

4

Back

Close

Full Screen / Esc

Printer-friendly Version

Interactive Discussion 
229, 1994.

Hernandez, K. L., Quinones, R. A., Daneri, G., and Elbing, E. W.: Effects of solar radiation on bacterioplankton production in the upwelling system off central-southern Chile, Mar. Ecol. Prog. Ser., 315, 19-31, 2006.

5 Jeffrey, W. H., Aas, P., Maille Lyons, M., Coffin, R. B., Pledger, R., and Mitchell, D. L.: Ambient solar radiation induced photodamage in marine bacterioplankton, Photochem. Photobiol., 64, 419-427, 1996.

Jin, Z., Charlock, T. P., Smith Jr., W. L., and Rutledge, K.: A parameterization of ocean surface albedo, Geophys. Res. Lett., 31, L22301, doi:10.1029/2004GL021180, 2004.

10 Joux, F., Jeffrey, W. H., Lebaron, P., and Mitchell, D. L.: Marine bacterial isolates display diverse responses to UV-B radiation, Appl. Environ. Microbiol., 65, 3820-3827, 1999.

Kaiser, E. and Herndl, G.: Rapid recovery of marine bacterioplankton activity after inhibition by UV radiation in coastal waters, App. Environ. Microbiol., 63, 4026-4031, 1997.

Kirchman, D. L.: Leucine incorporation as a measure of biomass production by heterotrophic 15 bacteria, in: Handbook of methods in aquatic microbial ecology, edited by: Kemp, P. F., Sherr, B. F., Sherr, E. B., and Cole, J. J., Boca Raton, Lewis, 509-512, 1993.

Kuhn, P., Browman, H., McArthur, B., and St-Pierre, J.-F.: Penetration of ultraviolet radiation in the waters of the estuary and Gulf of St. Lawrence, Limnol. Oceanogr., 44, 710-716, 1999.

Kuipers, B., VanNoort, G. J., Vosjan, J., and Herndl, G. J.: Diel periodicity of bacterioplankton

20 in the euphotic zone of the subtropical Atlantic Ocean, Mar. Ecol. Prog. Ser., 201, 13-25, 2000.

Landry, M. R. and Kirchman, D. L.: Microbial community structure and variability in the tropical Pacific, Deep-Sea Res. II, 49, 2669-2693, 2002.

Maranon, E., Cermeno, P., and Perez, V.: Continuity in the dissolved organic carbon production 25 of DOC from eutrophic to oligotrophic waters, Mar. Ecol. Prog. Ser., 299, 7-17, 2005.

Mopper, K. and Kieber, D. J.: Photochemistry and the cycling of carbon, sulfur, nitrogen, and phoshorus, in: Biogeochemistry of dissolved organic matter, edited by: Hansell, C. A. and Carlson, C. A., San Diego, Academic Press, 456-508, 2002.

Moran, X. A., Massana, R., and Gasol, J. M.: Light conditions affect the measurement of 30 oceanic bacterial production via leucine uptake, Appl. Environ. Microbiol., 67, 3795-3801, 2001.

Morel, A., Gentili, B., Claustre, H., Babin, M., Bricaud, A., Ras, J., and Tieche, F.: Optical properties of the "clearest" natural waters, Limnol. Oceanogr., 52, 217-229, 2007.

BGD

$5,435-462,2008$

Diel changes of BP and UV in the South Pacific

F. Van Wambeke et al.

Title Page

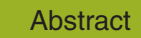

Introduction

Conclusions

Tables

References

Figures

14

-1

4

Back

Close

Full Screen / Esc

Printer-friendly Version

Interactive Discussion 
Myhre, G., Stordal, F., Johnsrud, M., Diner, D. J., Geogdzhayev, I. V., Haywood, J. M., Holben, B. N., Holzer-Popp, T., Ignatov, A., Kahn, R. A., Kaufman, Y. J., Loeb, N., Martonchik, J. V., Mishchenko, M. I., Nalli, N. R., Remer, L. A., Schroedter-Homscheidt, M., Tanre, D., Torres, O., and Wang, M.: Intercomparison of satellite retrieved aerosol optical depth over ocean during the period September 1997 to December 2000, Atmos. Chem. Phys., 5, 1697-1719, 2005 ,

http://www.atmos-chem-phys.net/5/1697/2005/.

Obernosterer, I., Ruardij, P., and Herndl, G.: Spatial and diurnal dynamics of dissolved organic matter (DOM) fluorescence and $\mathrm{H}_{2} \mathrm{O}_{2}$ and the photochemical oxygen demand of surface water DOM across the subtropical Atlantic Ocean, Limnol. Oceanogr., 46, 632-643, 2001.

Raimbault, P., Garcia, N., and Cerutti, F.: Distribution of inorganic and organic nutrients in the South Pacific Ocean - evidence for long-term accumulation of organic matter in nitrogendepleted waters, Biogeosciences Discuss., 4, 3041-3087, 2007, http://www.biogeosciences-discuss.net/4/3041/2007/.

Ras, J., Claustre, H., and Uitz, J.: Spatial variability of phytoplankton pigment distributions in the Subtropical South Pacific Ocean: comparison between in situ and predicted data, Biogeosciences Discuss., 4, 3409-3451, 2007, http://www.biogeosciences-discuss.net/4/3409/2007/.

Robarts, R. D., Zohary, T., Waiser, M. J., and Yacobi, Y. Z.: Bacterial abundance, biomass, and production in relation to phytoplankton biomass in the Levantine Basin of the southeastern Mediterranean Sea, Mar. Ecol. Prog. Ser., 137, 273-281, 1996.

Sempéré, R., Tedetti, M., Panagiotopoulos, C., Charrière, B., and Van Wambeke, F.: Distribution and bacterial availability of dissolved neutral sugars in the South East Pacific, Biogeosciences Discuss., in press, 2008.

Setlow, R. B.: The wavelengths in sunlight effective in producing skin cancer: a theoretical analysis, Proceed. Nat. Acad. Sci., 71, 3363-3366, 1974.

Sherr, E., Sherr, B., and Cowles, T.: Mesoscale variability in bacterial activity in the North East Pacific Ocean off Oregon, USA, Aquat. Microb. Ecol., 25, 21-30, 2001.

Sherr, B. F. and Sherr, E. B.: Community respiration/production and bacterial activity in the upper water column of the central Arctic Ocean, Deep-Sea Res. I, 50, 529-542, 2003.

Shiah, F. K.: Diel cycles of heterotrophic bacterioplankton abundance and production in the ocean surface waters, Aquat. Microb. Ecol., 17, 239-246, 1999.

Smith, D. C. and Azam, F.: A simple, economical method for measuring bacterial protein syn-
BGD

5, 435-462, 2008

Diel changes of BP and UV in the South Pacific

F. Van Wambeke et al.

Title Page

Abstract

Introduction

Conclusions

References

Tables

Figures

14

4

Back

Close

\section{Full Screen / Esc}

Printer-friendly Version

Interactive Discussion 
thesis rates in sea water using 3H-Leucine, Mar. Microb. Food Webs, 6, 107-114, 1992.

Tedetti, M., Sempéré, R., Vasilkov, A., Charrière, B., Nérini, D., Miller, W. L., Kawamura, K., and Raimbault, P.: High penetration of ultraviolet radiation in the south east Pacific waters, Geophys. Res. Lett., 34, L12610, doi:10.1029/2007GL029823, 2007.

5 Torréton, J. P. and Dufour, P.: Temporal and spatial stability of bacterioplankton biomass and productivity in an atoll lagoon, Aquat. Microb. Ecol., 11, 251-261, 1996.

Van Wambeke, F., Bonnet, S., Moutin, T., Raimbault, P., Alarçon, G., and Guieu, C.: Factors limiting heterotrophic bacterial production in the southern Pacific Ocean, Biogeosciences Discuss., 4, 3799-3828, 2007a.

10 Van Wambeke, F., Obernosterer, I., Moutin, T., Duhamel, S., Ulloa, O., and Claustre, H.: Heterotrophic bacterial production in the South East Pacific: Longitudinal trends and coupling with primary production, Biogeosciences Discuss., 4, 2761-2791, 2007b.

Visser, P. M., Jaap Poos, J., Scheper, B. B., Boelen, P., and Van Duyl, F. C.: Diurnal variations in depth profiles of UV-induced DNA damage and inhibition of bacterioplankton production in tropical coastal waters, Mar. Ecol. Prog. Ser., 228, 25-33, 2002.

Wilhelm, S. W., Jeffrey, W. H., Suttle, C. A., and Mitchell, D. L.: Estimation of Biologically Damaging UV Levels in Marine Surface Waters with DNA and Viral Dosimeters, Photochem. Photobiol., 76, 268-273, 2002.

Winter, C., Herndl, G., and Weinbauer, M.: Diel cycles in viral infection of bacterioplankton in the North Sea, Aquat. Microb. Ecol., 35, 207-216, 2004.

Zohary, T. and Robarts, R. D.: Bacterial numbers, bacterial production, and heterotrophic nanoplankton abundance in a warm core eddy in the Eastern Mediterranean, Mar. Ecol. Prog. Ser., 84, 133-137, 1992.

\section{BGD}

$5,435-462,2008$

Diel changes of BP and UV in the South Pacific

F. Van Wambeke et al.

Title Page

Abstract

Introduction

Conclusions

References

Tables

Figures

14

$\rightarrow$

4

Back

Close

Full Screen / Esc

Printer-friendly Version

Interactive Discussion 
Table 1. Main physical, biological and optical characteristics of the sites MAR, GYR and EGY. $Z_{e}$ : depth of the euphotic zone (1\% PAR), $Z_{m}$ : depth of the mixed layer, $Z_{10 \%}$ (UVB) and $Z_{10 \%}$ (UVA): $10 \%$ UVB and UVA irradiance depths determined close to solar noon (at 305 and $380 \mathrm{~nm}$, respectively), TChla: Total chlorophyll a (after Ras et al., 2007), BP: heterotrophic bacterial production. Mean \pm SD came from a varying number of profiles, minimum 6 (data of TChla).

\begin{tabular}{lccc}
\hline Site & MAR & GYR & EGY \\
\hline Position & $8.4^{\circ} \mathrm{S}, 141.2^{\circ} \mathrm{W}$ & $25.9^{\circ} \mathrm{S}, 114^{\circ} \mathrm{W}$ & $31.8^{\circ} \mathrm{S}, 91.4^{\circ} \mathrm{W}$ \\
Date & $26-30$ Oct & $12-16 \mathrm{Nov}$ & $25-30 \mathrm{Nov}$ \\
Temperature at $5 \mathrm{~m}\left({ }^{\circ} \mathrm{C}\right)$ & $27.8 \pm 0.06$ & $22.3 \pm 0.14$ & $18.1 \pm 0.03$ \\
$Z_{e}(\mathrm{~m})$ & $72 \pm 5$ & $155 \pm 9$ & $92 \pm 2$ \\
$Z_{m}(\mathrm{~m})$ & $89 \pm 9$ & $46 \pm 27$ & $32 \pm 4$ \\
$Z_{10 \%}(\mathrm{UVB})(\mathrm{m})$ & $11 \pm 1$ & $23 \pm 2$ & $14 \pm 1$ \\
$Z_{10 \%}(\mathrm{UVA})(\mathrm{m})$ & $38 \pm 3$ & $110 \pm 9$ & $57 \pm 4$ \\
Depth of TChla max $(\mathrm{m})$ & $53 \pm 15$ & $176 \pm 9$ & $73 \pm 10$ \\
TChla max concentration $\left(\mathrm{mg} \mathrm{m}^{-3}\right)$ & $0.38 \pm 0.05$ & $0.166 \pm 0.008$ & $0.25 \pm 0.11$ \\
BP at $5 \mathrm{~m}\left(\mathrm{ng} \mathrm{Cl} \mathrm{I}^{-1} \mathrm{~h}^{-1}\right)$ & $63 \pm 15$ & $17 \pm 7$ & $29 \pm 18$ \\
Integrated BP to $Z_{e}\left(\mathrm{mg} \mathrm{C} \mathrm{m}^{-2} \mathrm{~d}^{-1}\right)$ & $168 \pm 22$ & $65 \pm 11$ & $59 \pm 11$ \\
Integrated BP to $Z_{m}\left(\mathrm{mg} \mathrm{C} \mathrm{m}^{-2} \mathrm{~d}^{-1}\right)$ & $197 \pm 25$ & $19 \pm 4$ & $21 \pm 4$ \\
\hline
\end{tabular}

Diel changes of BP and UV in the South Pacific

F. Van Wambeke et al.

Title Page

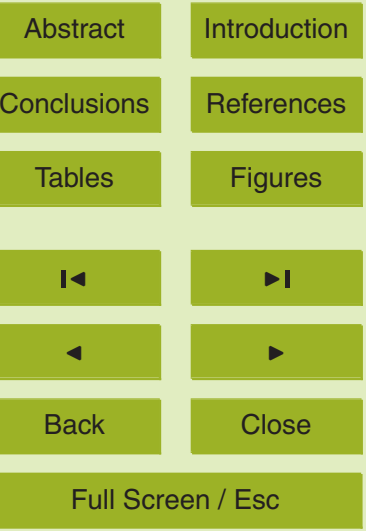

Printer-friendly Version

Interactive Discussion 
BGD

$5,435-462,2008$

Diel changes of BP and UV in the South

Pacific

Table 2. Percentage of $\mathrm{BP}$ variability (VAR) and correlation coefficients $(r)$ between volumetric rates $\left(\mathrm{BP}_{5 \mathrm{~m}}\right)$ and integrated data $\left(\mathrm{IBP}_{Z e}\right.$ or $\left.\mathrm{IBP}_{Z m}\right)$. n: number of data, ${ }^{*} p<0.05,{ }^{* \star} p<0.001$, ns: correlation not significant.

\begin{tabular}{lccc}
\hline Site & MAR & GYR & EGY \\
\hline & $\%$ & $\%$ & $\%$ \\
VAR BP $_{5 m}$ & 24 & 40 & 36 \\
VAR IBP $_{Z m}$ & 13 & 22 & 19 \\
VAR IBP $_{Z e}$ & 13 & 16 & 19 \\
\hline & $\mathrm{r}(\mathrm{n})$ & $\mathrm{r}(\mathrm{n})$ & $\mathrm{r}(\mathrm{n})$ \\
correlation $\mathrm{BP}_{5 \mathrm{~m}}-\mathrm{IBP}_{Z m}$ & $0.57(13)^{\star}$ & $0.88(16)^{\star *}$ & $0.90(9)^{\star *}$ \\
correlation $\mathrm{BP}_{5 \mathrm{~m}}-\mathrm{IBP}_{Z e}$ & $0.61(13)^{\star}$ & $0.55(16)^{\star}$ & $\mathrm{ns}$
\end{tabular}

Title Page

Abstract

Introduction

Conclusions

References

Tables

Figures

14

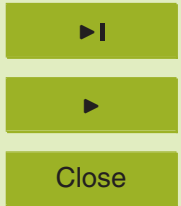

Back

Close

\section{Full Screen / Esc}

Printer-friendly Version

Interactive Discussion 
Table 3. Tri-hourly doses beneath the sea surface: $H\left(0^{-}, \mathrm{UVB}\right)$ and $H\left(0^{-}, \mathrm{UVA}\right)$, diffuse attenuation coefficients for downward irradiance: $K_{d}(\mathrm{UVB})$ and $K_{d}(\mathrm{UVA})$, depth of the mixed layer: $Z_{m}$, and mean tri-hourly doses within the mixed layer: $H_{m}(\mathrm{UVB})$ and $H_{m}(\mathrm{UVA})$. UVB is $305 \mathrm{~nm}$ and UVA is $380 \mathrm{~nm}$ as biologically effective wavelengths for the induction of DNA damages (CPDs) and photoenzymatic repairs (PERs), respectively. Daily is for the period 06:00-18:00.

\begin{tabular}{|c|c|c|c|c|c|c|c|c|}
\hline & $\begin{array}{c}H\left(0^{-}, \text {UVB }\right) \\
\left(\mathrm{kJ} \mathrm{m}^{-2} \mathrm{~nm}^{-1}\right)\end{array}$ & $\begin{array}{c}H\left(0^{-}, \mathrm{UVA}\right) \\
\left(\mathrm{kJ} \mathrm{m}^{-2} \mathrm{~nm}^{-1}\right)\end{array}$ & $\begin{array}{c}K_{d}(\text { UVB }) \\
\left(\mathrm{m}^{-1}\right)\end{array}$ & $\begin{array}{c}K_{d} \text { (UVA) } \\
\left(\mathrm{m}^{-1}\right)\end{array}$ & $\begin{array}{l}Z_{m} \\
(\mathrm{~m})\end{array}$ & $\begin{array}{c}H_{m}(\text { UVB }) \\
\left(\mathrm{kJ} \mathrm{m}^{-2} \mathrm{~nm}^{-1}\right)\end{array}$ & $\begin{array}{c}H_{m}(\text { UVA }) \\
\left(\mathrm{kJ} \mathrm{m}^{-2} \mathrm{~nm}^{-1}\right)\end{array}$ & $\begin{array}{c}Q=H_{m}(\mathrm{UVB}) / H_{m}(\mathrm{UVA}) \times \\
100(\%)\end{array}$ \\
\hline \multicolumn{9}{|l|}{ MAR (28 Oct) } \\
\hline 06:00-09:00 & 0.15 & 2.06 & 0.18 & 0.05 & 98 & 0.01 & 0.42 & 2.08 \\
\hline $09: 00-12: 00$ & 0.84 & 8.20 & 0.20 & 0.05 & 95 & 0.04 & 1.71 & 2.60 \\
\hline $12: 00-15: 00$ & 0.88 & 8.34 & 0.20 & 0.06 & 95 & 0.05 & 1.41 & 3.29 \\
\hline $15: 00-18: 00$ & 0.22 & 2.96 & 0.18 & 0.05 & 97 & 0.01 & 0.61 & 2.10 \\
\hline Daily & 2.09 & 21.56 & & & & 0.11 & 4.15 & 2.65 \\
\hline \multicolumn{9}{|l|}{ GYR (13 Nov) } \\
\hline 06:00-09:00 & 0.12 & 1.58 & 0.09 & 0.02 & 80 & 0.02 & 0.79 & 2.03 \\
\hline $09: 00-12: 00$ & 0.73 & 7.15 & 0.09 & 0.02 & 50 & 0.16 & 4.52 & 3.53 \\
\hline $12: 00-15: 00$ & 0.99 & 9.54 & 0.10 & 0.02 & 30 & 0.31 & 7.08 & 4.41 \\
\hline $15: 00-18: 00$ & 0.16 & 2.20 & 0.09 & 0.02 & 30 & 0.06 & 1.70 & 3.25 \\
\hline Daily & 2.00 & 20.47 & & & & 0.55 & 14.09 & 3.90 \\
\hline \multicolumn{9}{|l|}{ EGY (26 Nov) } \\
\hline 06:00-09:00 & 0.09 & 1.30 & 0.16 & 0.04 & 30 & 0.02 & 0.80 & 2.29 \\
\hline 09:00-12:00 & 0.38 & 4.08 & 0.16 & 0.04 & 30 & 0.08 & 2.49 & 3.12 \\
\hline $12: 00-15: 00$ & 0.59 & 5.73 & 0.16 & 0.04 & 32 & 0.11 & 3.40 & 3.35 \\
\hline $15: 00-18: 00$ & 0.20 & 2.30 & 0.16 & 0.04 & 32 & 0.04 & 1.36 & 2.82 \\
\hline Daily & 1.26 & 13.41 & & & & 0.25 & 8.05 & 3.10 \\
\hline
\end{tabular}

Diel changes of BP and UV in the South Pacific

F. Van Wambeke et al.

Title Page

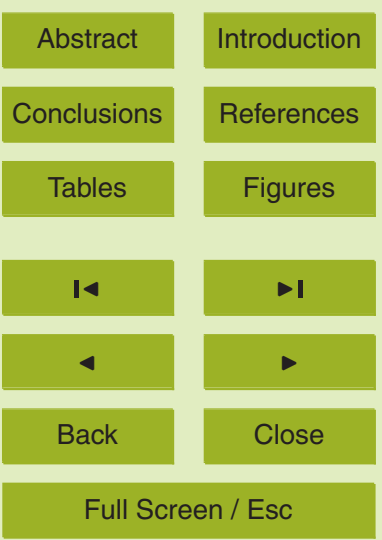

Printer-friendly Version

Interactive Discussion 
BGD

$5,435-462,2008$

Diel changes of BP and UV in the South

Pacific

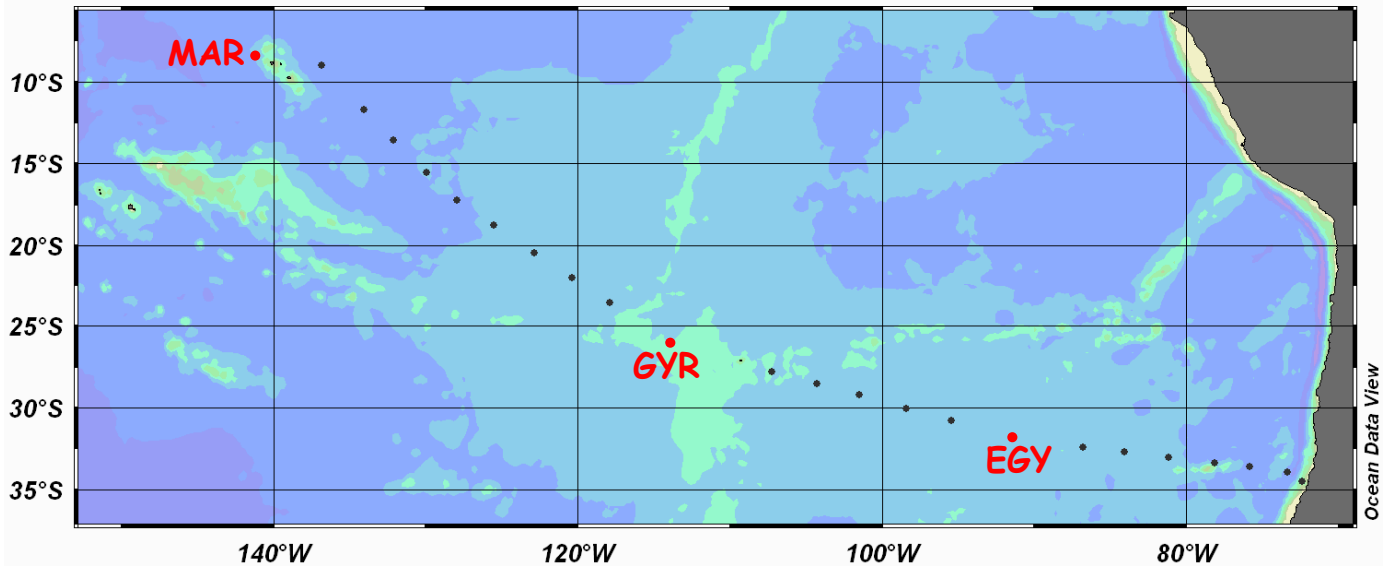

Fig. 1. Map of the BIOSOPE cruise track and location of the three long sites studied: Marquesas Islands (MAR), centre of the South Pacific Gyre (GYR) and eastern part of the South Pacific Gyre (EGY).
Title Page

Abstract

Introduction

Conclusions

References

Tables

Figures

14

4

Full Screen / Esc

Printer-friendly Version

Interactive Discussion 


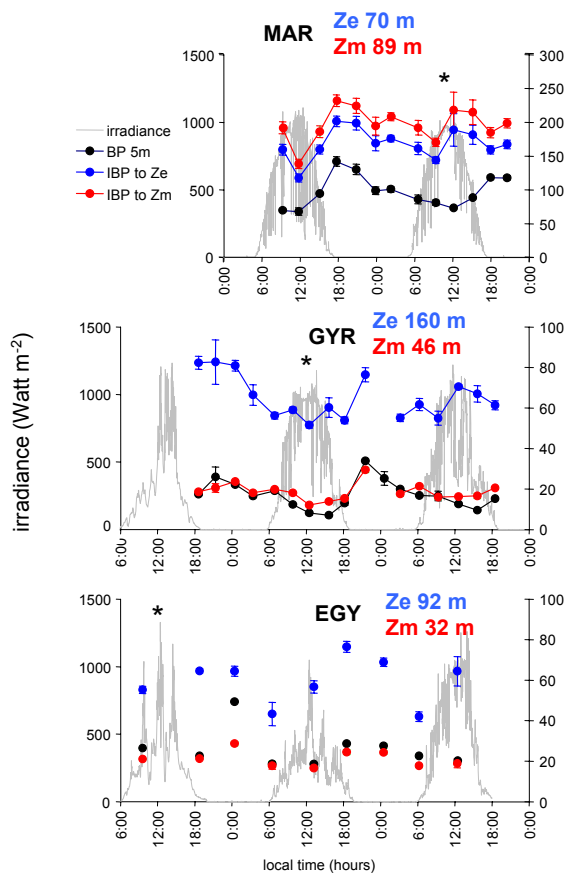

Fig. 2. Evolution of heterotrophic bacterial production (BP) at $5 \mathrm{~m}$ depth, integrated BP down to $Z_{e}$ and down to $Z_{m}$, and surface PAR irradiance with time at the three long sites, i.e. MAR, GYR and EGY. Integration depths corresponded to $Z_{e}$ and $Z_{m}$. Sampling period and frequency for BP measurements were at the site MAR: every $3 \mathrm{~h}$ from 27 October 09:00 to 28 October 21:00, at the site GYR: every $3 \mathrm{~h}$ from 12 November $18: 00$ to 14 November $18: 00$ and at the site EGY: every $6 \mathrm{~h}$ from 26 November 18:00 to 28 November 12:00 (plus one isolated data point at 09:00 on 26 November). During these time series, $Z_{e}$ was fixed to depth of $1 \%$ incident PAR, i.e. $72 \mathrm{~m}$ at the site MAR, $155 \mathrm{~m}$ at the site GYR and $92 \mathrm{~m}$ at the site EGY and we used a constant depth for $Z_{m}$ (averages of Table 1, i.e. $89 \mathrm{~m}$ at MAR, $46 \mathrm{~m}$ at GYR and $32 \mathrm{~m}$ at EGY). * Shows the days (MAR: 28 October, GYR: 13 November, EGY: 26 November) for which $H_{m}(\mathrm{UVB})$ and $H_{m}(\mathrm{UVA})$ were calculated (see Table 3). Error bars indicates standard deviation.
BGD

5, 435-462, 2008

Diel changes of BP and UV in the South Pacific

F. Van Wambeke et al.

Title Page

Abstract

Introduction

Conclusions

References

Tables

Figures

14

$\rightarrow$

4

Back

Close

\section{Full Screen / Esc}

Printer-friendly Version

Interactive Discussion 


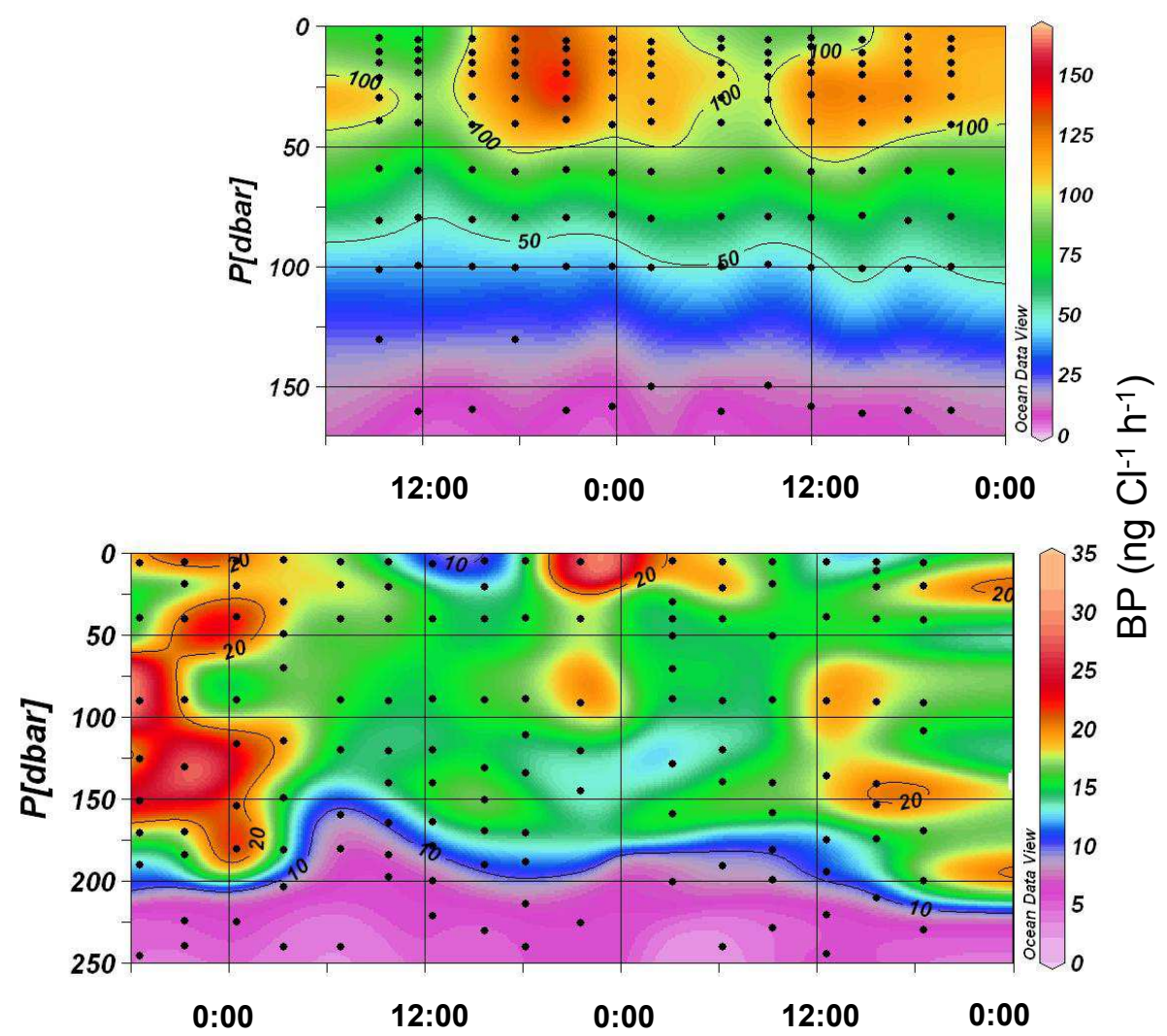

Fig. 3. Contour plots of heterotrophic bacterial production (BP) with time at the sites MAR (0$175 \mathrm{~m})$ and GYR $(0-250 \mathrm{~m})$. The time periods considered are the same as on Fig. 2. Note the different color scales for BP between the two sites.
BGD

$5,435-462,2008$

Diel changes of BP and UV in the South

Pacific

F. Van Wambeke et al.

\section{Title Page}

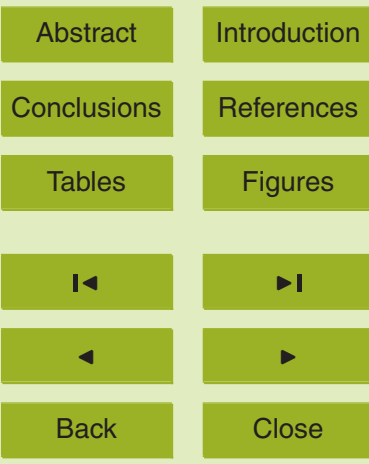

Full Screen / Esc

Printer-friendly Version

Interactive Discussion 
BGD

$5,435-462,2008$

\section{bacterial production $\left(\mathrm{ng} \mathrm{C}^{-1} \mathrm{~h}^{-1}\right)$}
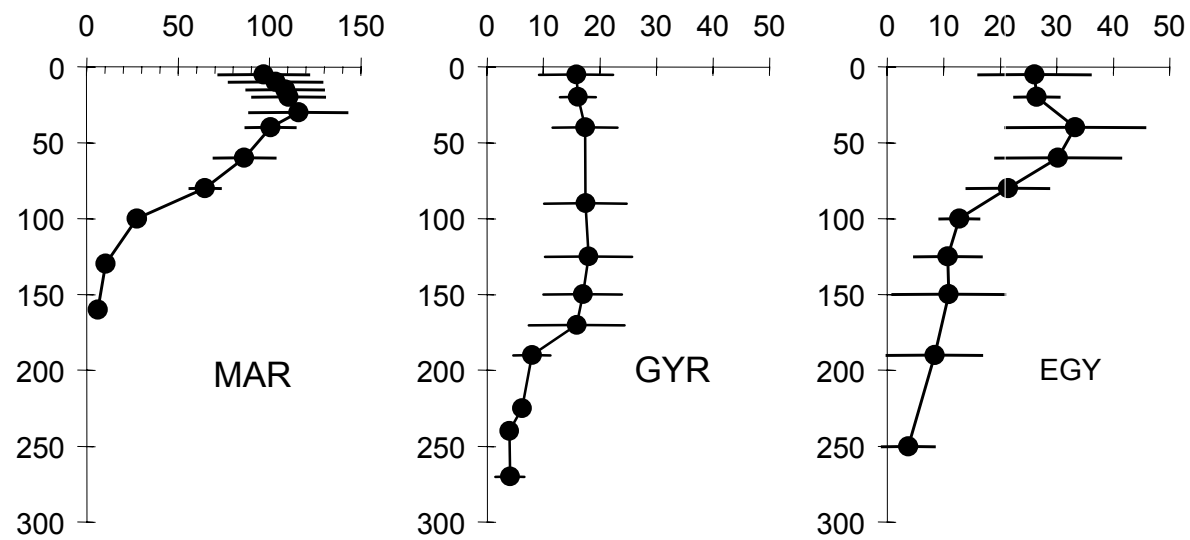

Fig. 4. Vertical profiles of mean heterotrophic bacterial production (BP) over diel cycle at the sites MAR (9 CTD casts, every $3 \mathrm{~h}$ from 27 November 09:00 to 28 November 09:00), GYR (9 CTD casts: every $3 \mathrm{~h}$ from 13 November 18:00 to 14 November 18:00) and EGY (8 CTD casts every $6 \mathrm{~h}$ from 26 November 18:00 to 28 November 12:00). Error bars indicates standard deviation.
Diel changes of BP and UV in the South

Pacific

F. Van Wambeke et al.

Title Page

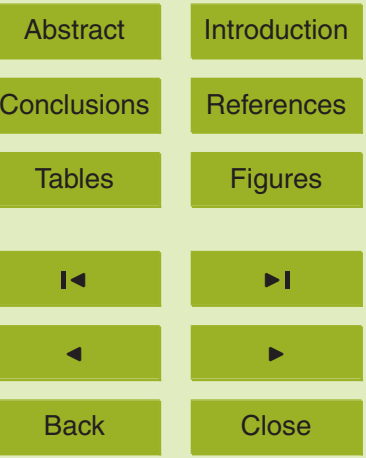

Full Screen / Esc

Printer-friendly Version 